\title{
Kaksoiskansalaisuuden turvallistaminen ja Suomen venäjänkieliset
}

Maailmanpolitiikan kehityskulkujen vaikutukset kohdistuvat Suomen venäjänkieliseen väestöön yhtäaikaisesti sekä Suomen että Venäjän valtiovallan toimien kautta. Tässä artikkelissa tarkastelemme kuinka Suomen ja Venäjän valtioiden poliittinen diskurssi turvallistaa Suomen venäjänkielistä väestöä heidän ulkomaansidonnaisuuksiensa kautta. Aiheessa yhdistyvät kansalaisuuden normien, transnationaalisuuden ja turvallisuuspolitiikan kysymykset. Venäjällä koko 2000-Iuvun jatkunut diskursiivinen ja juridinen kehitys kuvaa epäluottamusta ulkomaita ja niihin suhteessa olevia kansalaisia kohtaan, mutta samalla valtio on aktiivisesti rakentanut Venäjälle lojaalisuutta vaativaa diasporapolitiikkaa. Suomessa eduskunta on vuosina 2017 ja 2019 kiristänyt kaksoiskansalaisten pääsyä valtion virkoihin, mihin johtaneita prosesseja tarkastelemme aloitetta ajaneen puolustusministerin blogikirjoitusten ja niissä viitattujen dokumenttien kautta. Havainnollistamme, kuinka inmisten ulkomaansidonnaisuuksien turvallistaminen avaa laajoja mahdollisuuksia perusoikeuksiin puuttuviin toimenpiteisiin.

Teemu Oivo \&

OIga Davydova-Minguet

Voimakas muutos ulko- ja turvallisuuspolitiikan toimiympäristössä jatkuu niin Suomen lähialueilla kuin maailmanlaajuisesti, mikä lisää Suomen kansalliseen turvallisuuteen liittyviä uhkakuvia ja tekee niistä samalla myös arvaamattomia. Puolustusministeriö on 1.2.2017 puolustusministeri Jussi Niinistön päätöksellä asettanut lainsäädäntöhankkeen puolustusvoimista annetun lain ja Maanpuolustuskorkeakoulusta annetun lain muuttamiseksi siten, että puolustusvoimien sotilasvirkoihin voitaisiin jatkossa pääsääntöisesti 
nimittää vain sellaisia henkilöitä, joilla on ainoastaan Suomen kansalaisuus. (EDK-2017AK-107711.)

Venäjän maahanmuuttovirasto on langettanut sakot noin 43000 Venäjän kansalaiselle, jotka eivät ehtineet ajoissa ilmoittamaan virastolle toisesta kansalaisuudestaan. He joutuvat maksamaan sakot 500:sta tuhanteen ruplaan. Rikossyytteiden nostamisesta ei tiedoteta. (Meduza.io 2014.)

Vuosina 2013-2014 alkanut Ukrainan kriisi ja sitä seurannut geopoliittinen kehitys on vaikuttanut suoraan myös Suomen venäjänkieliseen väestöön. Niin Suomen kuin Venäjän suunnalta heihin kohdistuu monenlaisia epäluuloja ja paineita, jotka liittyvät heidän kaksoiskansalaisuuteensa ja laajemmin ottaen heidän monipaikkaiseen ja ylirajaiseen elämäntapaansa ja kuulumiseensa (Davydova 2009; Varjonen et al. 2013; Kananen et al. 2018; Oivo et al. 2019). Henkilöitä, joilla oli Suomen ja Venäjän kansalaisuus, oli Suomessa vuoden 2017 lopussa 30 088, mikä on lähes neljä kertaa enemmän kuin toiseksi suurin ryhmä, Ruotsin kansalaiset (SVT 2018). Ulkomaansidonnaisuudet ja Venäjän maanmiespolitiikka laajentavat aiheen käsittämään myös laajemmin Suomessa asuvia venäjänkielisiä, joita oli vuoden 2018 lopussa 77177 (SVT 2019; Lähteenmäki 2015). Tämä monimuotoinen joukko sisältää paitsi Venäjältä, myös useista entisen Neuvostoliiton eri maista muuttaneita sekä Suomessa syntyneitä ihmisiä. Valtiokeskeisen turvallisuusajattelun paluu on ajanut transnationaaleja ryhmiä - tässä tilanteessa Suomen venäjänkielisiä - ikään kuin "puun ja kuoren väliin" viime vuosien poliittisessa ja lainsäädännöllisessä kehityksessä (ks. Oivo et al. 2019).

Vaikka Venäjän kansalaisten osuus on selvästi alle puolet Suomen kaksoiskansalaisista, ovat he erityisesti profiloituneet kaksoiskansalaisuuskysymystä käsittelevässä julkisessa keskustelussa (Oivo 2018). Venäjällä puolestaan 2000-luvun lainsäädännön muutokset perustuivat ajatukseen toisten kansalaisuuksien vaarallisuudesta, ei pelkästään turvallisuusalalla vaan laajemminkin, muun muassa valtionhallinnossa, lainsäädännössä ja mediassa. Ulkomailla asuvat tai ulkomaihin suhteita omaavat Venäjän kansalaiset on esitetty ainakin potentiaalisesti epälojaaleina.

Tässä artikkelissa tuomme yhteen Suomen venäjänkielisen väestön perspektiivistä tarkasteltuna keskeiset Venäjällä ja Suomessa tapahtuneet prosessit, jotka ovat lisänneet heidän asemansa epävarmuutta ja turvattomuutta (Oivo et al. 2019). Pureudumme (kaksois)kansalaisuuden sekä yleisemmin ylirajaisten elämäntapojen ja siteiden merkityksen ymmärryksen muutokseen Suomessa ja Venäjällä. Ensin tuomme esille ajatteluamme ohjaavaa teoreettista keskustelua monikansalaisuuden ja turvallisuuden välisestä kytköksestä. Keskeiseksi tarkastelukulmaksemme olemme valinneet turvallistamisen näkökulman. Venäjän lainsäädännön kehityksen esittelemme lähinnä taustatiedoksi. Artikkelin keskeisenä teemana käsittelemme sitä, kuinka käsitykset Venäjästä ja sen kansalaisista näkyvät ja millaisiksi ne rakentuvat Suomen lainsäädäntöuudistuksen avainhenkilön, puolustusministeri Jussi Niinistön blogikirjoituksissa sekä niihin liittyvissä asiakirja- ja uutislähteissä. Tuomalla Venäjän lainsäädäntömuutoksia tämän analyysin taustaksi pyrimme ymmärtämään, mitkä rakenteelliset tekijät vaikuttavat venäjänkielisten tuntemukseen "puun ja kuoren välissä" olemisesta, josta he itse keskustelevat omaehtoisessa mediatoiminnassaan (Oivo et al. 2019). Vaikka Suomen laki ei rajoita kansalaisuuksien määrää kahteen (ja Venäjän laki ei tunnusta kaksoiskansalaisuutta paitsi silloin, kun se perustuu valtioiden kahdenkeskisiin sopimuksiin), viittaamme tässä artikkelissa monikansalaisuuteen kaksoiskansalaisuutena yleisimmin käytetyn termivalinnan mukaisesti. 
Artikkelimme kiinnittyy kriittiseen turvallisuuspoliittiseen keskustelun, joka kyseenalaistaa perinteistä valtiokeskeistä turvallisuuskäsitystä.

\section{Kansalaisuus ja turvallisuus}

Moderni kansalaisuuskäsitys perustuu westfalenilaiseen kansallisvaltioon, missä valtiovallan legitiimisyys tulee sen kansalaisilta (kansanvalta). Yksilön ja valtion välisiä oikeuksia ja velvollisuuksia määrittävän juridisen siteen lisäksi kansalaisuuteen voi sisältyä merkittäviä kuulumisen ja identifioitumisen ulottuvuuksia, joihin yhteiskuntatieteellinen kansalaisuustutkimus on kohdistunut. Kansalaisuuspolitiikka käsittelee toivotun tai aitona pidetyn yksilön ja valtion välisen siteen määrittelyä ja tunnistamista. (Faist 2007; Bauböck 2019.) Normatiivisen, niin sanotusti "kunnon kansalaisen" käsitteen on myös katsottu heijastavan ihanneyhteiskuntien jäsenten mallia (Mouffe 1988). Varsinkin toisen maailmansodan jälkeinen kansalaisuusteoretisointi sitoo sen myös hyvinvointivaltioon. T.H. Marshallin (1950) klassisen näkemyksen mukaan liberaali kansalaisuus sisältää kolme elementtiä: yksilölliset (taloudelliset) vapausoikeudet, poliittiset ja sosiaaliset oikeudet. Se on statuksenomainen ja tähtää kansalaisten tasa-arvoon. Vaikka sosiaaliset oikeudet eivät palaudukaan tyhjentävästi hyvinvointivaltioon, se on nähtävä tärkeänä välineenä niiden saavuttamiseksi. Tämä näkemys kansalaisuudesta sitoo sen myös demokraattiseen yhteiskuntajärjestykseen ja kapitalistiseen talouteen (ks. myös Kokkonen 2016).

Erityisesti 1900-luvun loppupuolella yleismaailmalliset normit, kuten kapitalismi, kansainvälinen oikeus ja ihmisoikeudet, ovat haastaneet westfalenilaisen valtion suvereniteetin korostaen yksilön oikeuksia kansalaisoikeuksien sijaan. Vaikka tämän seurauksena kaksoiskansalaisuuden vastustus on vähentynyt useissa maissa, vaihtelee siihen suhtautuminen edelleen maailmanlaajuisesti paljon. (Benhabib \& Post 2006; Faist 2007.) Arvojen ja yleismaailmallisen kehityssuunnan lisäksi myös naapurivaltioiden käytännöt vaikuttavat valtioiden kansalaisuuspolitiikkaan (Vink et al. 2019).

Jopa Euroopan unionissa, jossa ylikansallista EU-kansalaisuutta on kehitetty poliittisten ja tilallisten oikeuksien tasolla, westfalenilaisen suvereniteetin ytimessä oleva domaine reserve -oikeus määritellä jäsenyyskriteerejä on pysynyt valtiovallan ytimessä (Bauböck 2019, 6). EU-maat soveltavat kansalaisuuden myöntämisen (ja menettämisen) kriteereinä erilaisia painotuksia, kuten ihmisen syntymävaltioon perustuvaa jus soli ja vanhempiin perustuvaa jus sanguinis -periaatteita, joita täydennetään erilaisilla mahdollisuuksilla hankkia kansalaisuus (kansalaistaminen). Unionilla ei myöskään ole yhtenäistä linjaa kaksoiskansalaisuuden suhteen, vaikka sen sallimista kannustetaankin unionin yleisissä periaatelinjauksissa. (Mentzelopoulou \& Dumbrava 2018.)

Harva nykyvaltio määrittelee kansalaisuutensa etnisyyden perusteella. Sen merkityksellisyys näkyy kuitenkin edelleen kansalaistamis-, maahanmuutto-ja diasporapolitiikoissa. Muun muassa paluumuuttomenettelyn laajentaminen sellaisiin entisen Neuvostoliiton kansalaisiin, joilla on suomalaiset sukujuuret, on muodostanut "etuoikeutetun" väylän muuttaa Suomeen. Samalla se on vahvistanut käsitystä suomalaisuudesta periytyvänä etnis-kulttuurisena ominaisuutena, eikä niinkään kansalaisuuden kautta muodostuvana jäsenyytenä. (ks. Lepola 2000; Davydova 2009.) Suomessa vuonna 2003 voimaan tulleen usean kansalaisuuden sallivan lainsäädännön syntymisen taustalla vaikuttivat pyrkimykset vankistaa yhteyksiä ulkosuomalaisiin ja saada heitä muuttamaan "takaisin kotimaahansa" sukupolvienkin takaa (Ronkainen 2009, 16; LA 18011999 vp). 
Ylirajaisiin populaatioihin ja sitä kautta myös kaksoiskansalaisuuspolitiikkaan ovat Itä-ja Keski-Euroopassa vaikuttaneet suhteessa enemmän valtioiden rajojen muutokset verrattuna Länsi-Euroopassa korostuvaan muuttoliikkeeseen. Vastaavasti, siinä missä Länsi-Euroopassa kaksoiskansalaisuuspolitiikkaa on kannatettu tarkoituksenmukaisesti haastettaessa westfalenilaisen suvereniteetin valtaa ja kansallisvaltioajattelua, on Itä-Euroopassa kaksoiskansalaisuutta suosiva politiikka ollut usein päinvastoin lähtökohdiltaan kansallismielistä. Historian rajamuutokset saattavat tuoda revisionistisen elementin "historiallisen kotimaan" kansalaisuuspolitiikalle. Kaksoiskansalaisten asuinvaltiossa tämä taas voi kääntyä itsemääräämisoikeuteen ja rajojen koskemattomuuteen liittyväksi turvallisuuskysymykseksi. Näitä kysymyksiä on tutkittu muun muassa Unkarin, Romanian ja Moldovan (esim. Bauböck 2007) sekä Baltian maiden näkökulmista (esim. Skulte-Ouaiss 2015).

Territoriaalisten rajojen lisäksi kansallisen identiteetin turvallisuusmääritelmiin liittyy myös sosiaalinen erotus: se, mitä "meidän" tulisi pelätä on riippuvainen siitä, mitä "me" olemme (Campbell 1998, 73). Sikäli kun turvallisuuden problematisoinnin esitetään riippuvan kansallisvaltion enemmistöksi määritetystä "meistä", on vähemmistöt sidottu yhteiskunnallisen turvallisuuden ongelmaksi ja heidän etunsa nollasummapelisuhteeseen enemmistön kansanvallan ja kansallisen turvallisuuden kanssa (Kinnvall 2004, 763). Erityisesti kansallisia vähemmistöjä, joiden lähtö- tai sukulaisvaltiota pidetään vihollisvaltiona tai jotka asuvat lähellä "kansallisvaltionsa" vastaista rajaa, on historian saatossa kohdeltu usein "viidensinä kolonnoina" (Triadafilopoulos 2007, 31).

Kaksoiskansalaisuuspolitiikka liittyy siis kysymyksiin valtion rajoista, (kansan)vallasta ja ylirajaisten yhteisöjen suhteesta kansallisiin identiteetteihin. Myra Waterburyn (2010) mukaan valtion rajojen ulkopuoliset populaatiot on alettu diskursiivisen muutoksen myötä nähdä valtion eliittien perspektiivistä kulttuurisena, materiaalisena ja poliittisena vahvuutena. Tämän seurauksena useat valtiot ovat alkaneet harjoittaa diasporapolitiikkoja, jotka diskursiivisesti ja käytännöllisesti tuottavat "diasporaa" ja käsitystä kansakunnasta, joka on valtion maantieteellistä territoriota laajempi. Yli puolet nykymaailman valtioista harjoittaakin diasporapolitiikkaa (Délano Alonso \& Mylonas 2019). Diasporapolitiikkojen avulla luodaan mielikuvia väestöistä, joilla on "luontaista" lojaalisuutta ja yhteyttä "emovaltioon". Alan Gamlen (2006, 4-5) puhuukin diasporapolitiikoista ylirajaisen hallinnan muotona: ne tuottavat ja uusintavat "kansalainen-suvereeni -suhdetta ekspatriaattien kanssa, ja sitä kautta hallinta muuttuu ylirajaiseksi". Toki diasporapolitiikkojen eri muodot on syytä nähdä monitasoisen toimijuuden kenttinä: niitä eivät harjoita yksinomaan valtiot, vaan toimijoiden kirjo voi olla laaja, ja diasporiset väestöt reagoivat niihin eri tavoin (Délano Alonso \& Mylonas 2019).

Turvallisuustutkimus on aina kehittynyt maailman muuttuvien olosuhteiden mukaan. Esimerkiksi rauhantutkimus, inhimillinen turvallisuus ja kriittinen turvallisuustutkimus ovat haastaneet ja pyrkineet laajentamaan perinteisiltä lähtökohdiltaan sotilaallista ja valtiokeskeistä ("kansallinen turvallisuus", raison d'état) turvallisuustutkimusta (Buzan \& Hansen 2009). Tarkastelemme Suomen venäjänkielisiin kohdistuvaa politiikkaa kööpenhaminalaisen koulukunnan käsitteellistämän turvallistamisen avulla. Turvallistaminen sitoutuu kansalliseen turvallisuusdiskurssiin, missä korostuvat valtion ylin toimivalta, uhkien ja vihollisten kohtaaminen (ja konstruointi) sekä poikkeustilan päätösvalta. Turvallistamisprosessissa keskustelun kohteena oleva asia esitetään turvallisuustermein ja erityisesti eksistentiaalisena uhkana, jolloin turvallistetun asian käsittely erotetaan tavanomaisista poliittisen päätöksenteon prosesseista. (Buzan \& Hansen 2009, 213-214.) Käytämme turvallistamista tutkimuskäsitteenä tarkastellaksemme eri tavoin ja vaihtelevasti ilmentyviä vallankäytön tapoja. Juridisen 
ja diskursiivisen aineiston tarkastelun avulla voidaan havainnoida sitä, mitä turvallistavalla vallankäytöllä tehdään mahdolliseksi. Sen tosiasiallisten vaikutusten tutkimus vaatii käytäntöihin ja ihmisten kokemuksiin perustuvaa aineistoa.

Asioiden ja ihmisten turvallistaminen voi olla ongelmallista ja jopa vaarallista sen kohteille (esim. Kinnvall 2004). Lisäksi se rajaa päätösvaltaa pienille piireille ja mahdollistaa vallan väärinkäytön, kun vallankäytön prosesseista karsitaan kyseenalaistamisen ja haastamisen mahdollisuus objektiiviseen pakkoon vedoten. Turvallistaminen on kuitenkin vakavien turvallisuusuhkien kohdalla hyväksyttävänä pidetty käytäntö. Tämän mukaisesti esimerkiksi Suomen kaksoiskansalaisuuskysymyksen puolustusministeri Jussi Niinistö tunnusti olevan ongelmallinen perustuslain kannalta, mutta kansallisen turvallisuuden takaamiseksi poikkeuksellisesti hyväksyttävä (Kuivaniemi 2018). Lakeja ajanut diskurssi ei ollut sikäli turvallistava, että puolustusministeri ei esittänyt uhkia poikkeuksellisen nopeaa lainsäädäntöjärjestystä vaativana akuuttina selviytymiskysymyksenä (vrt. Buzan \& Hansen 2009, 213-214), vaikka hän pyrkikin saamaan rajoitukset voimaan jo vuoden 2018 alusta eikä vasta vuonna 2019 (EDK-2017-AK-107711). Niinistön blogitekstejä käsittelevässä artikkelin osassa keskitymme kritisoimaan lakialoitteisiin liittyvissä teksteissä esiintyvien turvallistamisdiskurssien näennäistä vääjäämättömyyttä sekä niiden vaikutuksia erityisesti Suomessa.

\section{Venäjän tiukkeneva kanta ulkomaansidonnaisuuksiin}

Rajatutkimuksessa on huomioitu, kuinka hallinnon mekanismien monipuolistuessa rajayhteisöt ovat joutuneet yhä enemmän yhtä aikaa kahden suvereenin valtion hallinnon/-an alaiseksi (Longo 2018, 66). Tämä ei koske yksinomaan valtioiden raja-alueiden asukkaita, vaan esimerkiksi Suomi-Venäjä -kaksoiskansalaiset ovat olleet yhtäaikaisesti kahden valtion hallinta- ja turvallistamisprosessien kohteena. Ulkomaansuhteita eli ulkomailla olevaa omaisuutta, ulkomaiden kansalaisuutta tai oleskelulupia on Venäjällä esitetty mahdollisena uhkana valtion turvallisuudelle koko 2000-luvun ajan. Samalla erinäisiä oikeuksia on rajoitettu yhä uusin säädöksin ulkomaan kansalaisilta sekä sellaisilta Venäjän kansalaisilta, joilla on myös toinen kansalaisuus. Tämä diskursiivinen ja lainsäädännöllinen kehitys ei suoranaisesti vaikuttanut valtaosaan Suomessa asuvista Venäjän (kaksois)kansalaisista, kunnes vuonna 2014 oli hyväksytty ulkomaan oleskelulupia ja kansalaisuuksia Venäjän valtiolle ilmoittamaan velvoittava laki. Näillä ulkomaansidonnaisuuksia turvallistavilla kehityskuluilla kuitenkin on ollut yleistä ulkomailla asuviin tai sinne muuttaviin kohdistuvaa epäluottamusta lietsova vaikutus.

Monikansalaisuus on neuvostoajan jälkeisellä Venäjällä ymmärretty ja sitä käsitelty liittyen Neuvostoliiton hajoamiseen, kansainvälisyyteen ja muuttoliikkeisiin (ks. Traunmüller \& Agarin 2015). Jos 1990-luvulla monikansalaisuuden voitiin nähdä edistävän maan kansainvälistymistä ja sen liittymistä globaaleihin muuttoliikkeisiin ja erityisesti talouteen, 2000-luvun kehitys tapahtui asteittaisessa "Lännen" oletettujen uhkien rajoittamisen ilmapiirissä. Keskustelussa toinen kansalaisuus näytetään käsitettävän kahtalaisena: ensisijaisesti instrumentalistisena, eri valtioiden kansalaisille suomien etujen yhdistämisen mahdollistavana välineenä ja siten oikaisua vaativana moraalisempaan, valtion ja kansalaisen yksinomaista sidettä ilmaisevaan suuntaan (Aksenov 2014). 2000-luvulta alkaen eri väestöryhmille on esitetty erinäisiä "kansallistamisvaateita", ja tätä yksinomaista kansalaisuutta vaativaa kansallistamistrendiä voidaan luonnehtia laajenevaksi. Venäläisissä kaksois- tai monikansalaisuutta käsittelevissä teksteissä (esim. Sazonov 2014) korostetaan kaksoiskansalaisuuden ja toisen 
kansalaisuuden välinen ero: kaksoiskansalaisuus tunnustetaan sellaiseksi vain jos Venäjä on solminut sopimuksen toisen valtion kanssa. Nykyään näin ymmärretty kaksoiskansalaisuus sallitaan vain Tadžikistanin kanssa solmitun sopimuksen nojalla, ja vuosina 1993-2015 vastaavanlainen sopimus toimi Turkmenistanin kanssa. Muissa tapauksissa, vaikka kansalaisella olisikin toisen valtion kansalaisuus, Venäjä kohtelee häntä yksinomaan omana kansalaisena.

Periaatteessa Venäjän vuonna 1993 hyväksytty perustuslaki sallii Venäjän kansalaiselle toisten valtioiden kansalaisuudet ja toteaa, ettei niiden pidä kaventaa tämän oikeuksia taikka vapauttaa velvollisuuksista, ellei federaation laki tai kansainvälinen sopimus säädä muuta (KRF 2019). Kansalaisuuslaki puolestaan säätää, ettei toisen maan kansalaisuuden saaminen johda Venäjän federaation kansalaisuuden lakkautumiseen (N 62-FZ). Kuitenkin vuonna 2004 hyväksytty federaation laki valtion siviilipalvelusta (N 79-FZ [27.7.2004], s. 16) säätää Venäjän kansalaisuudesta luopumisen tai toisen kansalaisuuden hankkimisen perusteeksi virkasuhteen irtisanomiselle. Toinen kansalaisuus on este toimimiselle kaikissa valtion viroissa - esimerkiksi verohallinnossa, oikeuslaitoksessa, poliisissa ja turvallisuusviranomaisissa. Toinen kansalaisuus tai toisen valtion oleskelulupa on vuodesta 2006 säädetty esteeksi toiminnalle vaaleilla valituissa edustuselimissä, $\mathrm{mm}$. valtionduumassa, federaationeuvostossa, ja VF:n subjektien lainsäädäntöelimissä (N 128-FZ). Vuonna 2002 hyväksytty vaalilaki kielsi monikansalaisilta ja toisen valtion oleskeluluvan haltijoilta jäsenyyden vaalilautakunnissa (Cikrf.ru). Tämä lainkohta tuli osittain kumotuksi vuonna 2010 perustuslakituomioistuimen toimesta perustuslain vastaisena. Lainmuutokset ja niitä koskenut keskustelu kohdistuivat ensisijaisesti korkeassa asemassa oleviin duuman jäseniin, virkamiehiin sekä heidän perheenjäseniinsä, ja tämä niin sanottu "eliittien kansallistaminen" oli saanut paljon huomiota mediassa.

"Eliittien kansallistaminen" jatkui 2010-luvulla: vuonna 2013 oli hyväksytty laki, joka kielsi federaatio-, alue- ja kaupunkitason valtionvirkamiehiä, turvallisuus-, tulli- ja oikeusviranomaisia sekä kansanedustajia ja näiden perheenjäseniä omistamasta pankkitilejä, kiinteää omaisuutta sekä liiketoimintaa ulkomailla (79-FZ [7.5.2013]). Lain alullepanija, duuman jäsen Sergei Železnjak, on perustellut sen tarpeellisuuden muun muassa seuraavasti: "virkamiehellä ei voi olla taloudellisia sidonnaisuuksia muihin valtioihin, koska silloin hän tulee riippuvaiseksi toisten maiden johdon odotuksista, eikä Venäjän kansalaisten intresseistä" (Škel 2012). Tämä lausuma liittää toisessa valtiossa olevan taloudellisen toiminnan turvallisuusriskiin Venäjän valtiolle ja kansalaisille. Edellisenä vuonna käsiteltiin ja hyväksyttiin niin sanottu laki ulkomaalaisista agenteista. Se on suunnattu kansainvälistä rahoitusta saavia kansalaisjärjestöjä vastaan ja turvallistaa sekä kansainvälistä rahoitusta että kansalaisjärjestötoimintaa (ks. Oivo 2013). Sen tavoitteena oli rajoittaa myös valtiosta riippumattomien tutkimusorganisaatioiden toimintaa.

Krimin valtaus ja Itä-Ukrainan sodan alku vuonna 2014 ovat osaltaan vaikuttaneet mediaalaan kohdistuviin rajoituksiin. Ulkomaalaisten yritysten, järjestöjen, yksityishenkilöiden ja kaksoiskansalaisten toimintamahdollisuuksia on rajattu erityisen tarkkaan: syksyllä 2014 hyväksytyillä medialain muutoksilla (N 305-FZ) heidän mahdolliset kokonaisosuutensa joukkotiedotusvälineiden peruspääomassa rajoitettiin 20 prosenttiin. Kaksoiskansalaiset eivät voi myöskään perustaa joukkotiedotusvälineitä eivätkä toimia niissä päätoimittajina. Myös tämä laki rajoitti kaksoiskansalaisten (ainakin) taloudellisia oikeuksia ja laajensi turvallistettavan toiminnan piiriä. Ulkomaansidonnaisuuksia rajoittavat lait ainakin näyttävät lisänneen korkeissa asemissa olevien Venäjän kansalaisten epävarmuutta ja keskinäistä riippuvuutta. Ulkomaansidonnaisuudet eivät näyttäneet vähentyvän, mutta ne tulivat turvallistetuiksi ja 
riskitekijäksi niiden omistajille: ne voidaan olla huomaamatta, mutta niistä voidaan myös rangaista, ja käyttää niitä valtakamppailussa (Demoscope 2014).

Kesäkuussa 2014 hyväksyttiin duuman jäsen Andrei Lugovoin esittämät lisäykset Venäjän kansalaisuuslakiin ja muuhun lainsäädäntöön (N 142-FZ). Ne määräsivät Venäjän kansalaiset velvollisiksi ilmoittamaan Venäjän maahanmuuttoviranomaisille muiden maiden kansalaisuudet ja oleskeluluvat. Ilmoitukset säädettiin tehtäväksi migraatiopalvelulle 60 päivän kuluessa kansalaisuuden tai oleskeluluvan saamisesta sakon tai pakkotyön uhalla. Näitä muutoksia koskevassa keskustelussa korostui niiden kohdistuminen ensisijaisesti (korkea-arvoisiin) valtion virkamiehiin ja poliitikkoihin, mutta myös koko väestöön. Kaksoiskansalaisista ja muiden maiden oleskelulupien haltijoista puhuttiin "viidentenä kolonnana" ja "kansallispettureina". Nämä muutokset liittyivät edelleen yltyneeseen lännenvastaisuuteen ja geopoliittisen tilanteen käsittämiseen sotatilana. Andrei Kolesnikovin (2014) mukaan kyseiset lakimuutokset tekivät toisen kansalaisuuden tai ulkomaiden oleskeluluvan omaavista Venäjän kansalaisista automaattisesti epäluotettavia antaen valtiolle oikeuden valvoa ja syyttää heitä, minkä vuoksi ne ovat ristiriidassa Venäjän perustuslain kanssa. Toisesta kansalaisuudesta on tullut sen omistajalle hävettävä ja potentiaalisesti vaarallinen asia. Oikeudesta "tietää" on puhunut myös presidentti Putin: "meillä on perusteltu velvollisuus ja oikeus tietää, keitä asuu Venäjällä, ja mitä he tekevät" (Pertsev 2014).

Toisesta kansalaisuudesta tai oleskeluluvasta ilmoittamisen menettely ja ylipäänsä tiedotus asiasta on pitkään ollut epäselvää ja on herättänyt paljon huolestuneisuutta niin Venäjän sisällä kuin sen ulkopuolella. Sen lisäksi, että keskustelut kaksoiskansalaisuudesta ja ulkomaisista oleskeluluvista ovat heittäneet epäluotettavuuden varjon kaikkien sellaisten Venäjän kansalaisten päälle, joilla on ulkomaansuhteita, synnyttivät ne suoranaista pelkoa esimerkiksi rajan ylittämistä kohtaan: mistä alkaen aletaan laskea 60 päivää? Koskeeko se kaikkia Venäjän kansalaisia, niitäkin, jotka ovat asuneet ulkomailla vuosikausia? Entä lapsia? Yhtä epäselvä tilanne jatkui 2015-2016, kun Venäjällä hyväksyttiin joukko lakiehdotuksia, jotka velvoittivat Venäjän kansalaisia ilmoittamaan Venäjän veroviranomaisille rahaliikenteestä heidän ulkomaantileillään (ks. Alikina \& Stognei 2016). Nämä säädökset edelleen vahvistivat ulkomailla asuvien Venäjän kansalaisten aseman epämääräisyyden: ulkomailla asuessaan monet säilyttävät Venäjällä sijaitsevat asuntonsa, niissä rekisteröinnit ja Venäjän sisäiset passinsa - mitä lait eivät kiellä. Pitääkö nyt toimittaa Venäjän viranomaisille tiedot omista tileistä? (Ks. Oivo et al. 2019.)

Vuosien 2004-2016 Venäjän lainsäädökset ja niitä koskeva diskurssi vahvistivat kaksoiskansalaisuuteen, ulkomaiden oleskelulupiin ja ulkomailla oleviin tileihin tai omaisuuteen liitettävää epäluotettavuuden tai vaarallisuuden merkitystä. Ne laajensivat valvottavien piiriä valtakunnallisesti tai alueellisesti korkeissa poliittisissa tai taloudellisissa asemissa olevista tavallisiin kansalaisiin. Samalla Venäjän diasporapolitiikka (esim. Byford 2012; DavydovaMinguet 2014; Grigas 2016; Lähteenmäki 2015; Zhurzhenko 2017) on vahvistanut mielikuvaa ulkomailla asuvista Venäjän kansalaisista ja venäjänkielisistä osana Venäjän johtamaa ”venäläistä maailmaa" (Russkij mir), mikä puolestaan ikään kuin vaatii heiltä erityistä lojaalisuutta Venäjän valtiolle jopa ilman kansalaisuussidettä siihen.

Venäjän diasporapolitiikkaa on 1990-luvulta alkaen rakennettu vastaamaan Venäjän sisä-ja ulkopoliittisiin käytännön tarpeisiin joustavuutensa ansiosta hyvin soveltuvan maanmieskäsitteen avulla. Se kattaa Neuvostoliiton hajoamisen seuraamuksena muodostuneiden venäjänkielisten vähemmistöjen lisäksi myös Venäjältä vapaaehtoisesti muuttaneet ihmiset, joita kieli, arvot ja kulttuuri yhdistävät ylirajaiseen "venäläiseen maailmaan". Etnisesti, työvoima- 
ja aluepoliittisesti toivotun maahanmuuton lisäksi tällä politiikalla pyritään muokkaamaan tunteellisia siteitä Venäjään ja yhteenkuuluvuutta siihen. Tilanteen mukaan Venäjän diasporaa voidaan tulkita laajasti tai suppeasti, mutta siltä odotetaan erityistä lojaalisuutta Venäjän valtiota kohtaan. Toisaalta diasporan jäsenillä esitetään olevan erityisiä kulttuurisia, poliittisia ja taloudellisia oikeuksia, joiden tyydyttämistä Venäjä turvaa ja valvoo. "Maanmiesten" itsensä esitetään usein olevan Venäjän suojelun tarpeessa. "Maanmiehiltä" myös odotetaan liittymistä Venäjän valtion johtamiin ja koordinoimiin järjestöihin. Maanmiespolitiikkaa voi luonnehtia biopoliittiseksi, koska siinä korostuu näennäisen epäpoliittiseen ja objektiiviseen totuuskriteeriin perustuva vetoomus yhdistää populaatioita, ei niinkään territorioita. (Davydova-Minguet 2014; ks. myös Makarychev \& Yatsyk 2017.)

Andy Byford (2012) on luonnehtinut Venäjän maanmiespolitiikan myötä muodostuvaa diasporaa valtion funktioksi: se syntyy valtion toimitsijoiden myötä, mutta varsinaista ulkomailla asuvien venäläisten ja Venäjän valtion välistä suhdetta vaivaa syvä molemminpuolinen epäluottamus. Toisaalta Venäjän kannattajien joukko näyttää tiivistyvän Itä-Ukrainan sotaan liittyvän medioituneen propagandan synnyttämän isänmaallisuuden ja Venäjän harjoittaman muistinpolitiikan ansiosta (ks. esim. Davydova-Minguet 2018).

Ulkomailla asuvat Venäjän kansalaiset ja venäjänkieliset ovat Venäjän politiikkojen kohteena paradoksaalisessa asemassa: toisaalta suhde ulkomaihin ja näin ollen ulkomailla asuviin Venäjän kansalaisiin on Venäjän poliittisessa diskurssissa ja lainsäädännön toimesta turvallistettu, toisaalta Venäjän toisesta maailmansodasta, Itä-Ukrainan sekä Syyrian sodista ammentavat identiteettipolitiikat edellyttävät venäjänkielisiltä mobilisoitumista ja Venäjän maanmiespolitiikan mukaisen diasporan kiteytymistä (Zhurzhenko 2017; Davydova-Minguet et al. 2016). Tämän lisäksi Venäjä käyttää muitakin keinoja vahvistaakseen sidettä Venäjän kansalaisuuteen ulkomailla asuvien keskuudessa. Esimerkiksi toisen ja sitä seuraavan lapsen syntymästä myönnettävä "äidin pääoma" ei ole sidottu Venäjällä asumiseen, vaan ainoastaan äidin ja lasten Venäjän kansalaisuuteen (N 256-FZ), ja monet ulkomailla asuvat Venäjän kansalaiset käyttävät tätä etuutta. Näin muodostuva suhde Venäjään ja sen kansalaisuuteen on pikemminkin pragmaattinen, mutta seuraamuksiltaan mahdollisesti kauaskantoinen.

\section{Venäjänkieliset ja kaksoiskansalaisuuskysymys Suomessa}

Niin sanottu kaksoiskansalaisuuskysymys nousi Suomessa uutisotsikoihin elokuussa 2014, kun Yle uutisoi hallituksen pyytäneen selvitystä monikansalaisuuden sallimisesta lähimaissa ja kaksoiskansalaisuuden nykytilasta Suomessa (Lindqvist 2014). Ylen tietojen mukaan taustalla vaikuttivat tuolloin Venäjän kaksoiskansalaisten määrän nopea kasvu Suomessa viime vuosina sekä Venäjän maanmiespolitiikkaan liittynyt julistus, jonka mukaan maa tulee suojelemaan kansalaisiaan kaikkialla maailmassa. Sisäministeri Päivi Räsänen kommentoi Venäjän olevan vain yksi osa selvitystä. (Lindqvist 2014.) Seuraavan kerran kaksoiskansalaisuus nousi useisiin uutisotsikoihin alkuvuodesta 2017, jolloin Puolustusvoimissa uutisoitiin olleen otettu käyttöön Suomen ja Venäjän kaksoiskansalaisia syrjiviä sääntöjä. Puolustusministeri Niinistö kiisti jyrkästi nämä väitteet, mutta kertoi samalla valmisteilla olevasta lakihankkeesta, joka kansallisen turvallisuuden perusteella sulkisi kaksoiskansalaiset pois puolustusvoimien strategisista tehtävistä. (Happonen 2017c.)

Marraskuussa 2017 eduskunta päätti muutoksista turvallisuusselvityslakiin, joihin sisältyivät Suojelupoliisin eli Supon laajentuneet mahdollisuudet selvittää virkoihin hakijoiden ulkomaansidonnaisuuksia aiempaa kattavammin ja useamman tehtävän kohdalla. Päivitetyssä 
lain 3 §:n 1 momentin 9 a kohdassa ulkomaansidonnaisuudet määritetään seuraavasti:

[S]elvityksen kohteen selvityksen tekohetken ja aikaisempia kansalaisuuksia, toimimista toisen valtion palveluksessa, osallistumista elinkeinotoimintaan toisessa valtiossa, hänen toisessa valtiossa olevaa varallisuuttaan, hänen läheisiään, jotka ovat toisen valtion kansalaisia, hänen jatkuvia ja kiinteitä yhteyksiään toisen valtion kansalaisiin sekä hänen muita sidonnaisuuksiaan toiseen valtioon tai sen kansalaisiin ja yhteisöihin (...) (EV 1222017 vp.)

Ulkomaansidonnaisuuden määritelmässä turvallisuustarkastuksen kohteena olevan ylirajaiset juridiset, sosiaaliset, poliittiset ja taloudelliset siteet arvioidaan siis laajasti mahdollisina, joskaan ei kategorisina turvallisuusriskeinä. Vaikka arvio tehdään tehtävästä ja yksilöstä riippuen, voivat Suomi-Venäjä -kaksoiskansalaiset ja heidän läheisensä tulla hylätyiksi tässä prosessissa, sillä Venäjällä yleisen asevelvollisuuden ja laajan julkisen sektorin vuoksi monella on kokemusta valtion palveluksesta. Lisäksi 1990-luvun yksityistämisen vuoksi useilla perheillä on kiinteää omaisuutta Venäjällä ja ylirajaiset hoivasuhteet ovat yleisiä (Heino 2018; Davydova-Minguet \& Pöllänen 2018). Ulkomaansidonnaisuuteen viitattiin myös keväällä 2019 eduskunnan hyväksymässä puolustusministeriön ja sisäministeriön valmisteluiden pohjalta syntyneessä lakiuudistuspaketissa. Hyväksyttyjen lakien mukaan Maanpuolustuskorkeakouluun pääsevien ja samalla sekä Puolustusvoimien tai Rajavartiolaitoksen tehtävissä toimivalta henkilöltä vaaditaan:

[E]ttei hänellä ole sellaista toisen valtion kansalaisuutta tai muuta turvallisuusselvityslain (726/2014) $3 \S: n 1$ momentin 9 a kohdassa tarkoitettua ulkomaansidonnaisuutta, joka voi vaarantaa valtion turvallisuutta, yleistä turvallisuutta, maanpuolustusta tai Suomen kansainvälisiä suhteita taikka palvelusturvallisuutta Puolustusvoimissa tai Rajavartiolaitoksessa. (EV 2802018 vp.)

\section{Turvallistamisen logiikkaa Suomessa}

Tässä osiossa tarkastelemme ylirajaisten suhteiden ja erityisesti kansalaisuuden turvallistamisprosesseja Suomen puolustusministeri Jussi Niinistön henkilökohtaisen blogin kautta. Poliitikkojen blogikirjoituksia voidaan pitää päätöksenteon läpinäkyvyyttä edistävänä toimintana ja päätöksenteon perusteluna. Erityisesti puolustusministerin blogi on mielenkiintoinen tutkimusaineisto, sillä ulko- ja turvallisuuspolitiikka sisältää perinteisesti paljon julkisuudelta salattua tietoa. Julkisuus vaikuttaa kuitenkin oletettavasti paitsi sisällytettyihin asioihin, myös kirjoitusten esitystapaan. Ne soveltuvat kuitenkin vallan käytön oikeuttamisen ja lakialoitteiden välttämättömyyden peittämän vallan tarkastelemiseen.

Eduskuntakaudella 2015-2019 puolustusministerin virassa ollut Jussi Niinistö kirjoitti blogiinsa viisi kaksoiskansalaisuutta käsittelevää juttua (2016, 2017, 2018a, 2018b \& 2018c). Ne viittasivat 14 tunnistettavaan eri lähteeseen, joihin lukeutui lakialoitteita, uutisartikkeleita, voimassa olevaa lainsäädäntöä ja periaateohjelmia. Suuri osa lähteistä toimii argumentatiivisena tukena aloitteelle muuttaa kansalaisuuslainsäädäntöä. Rajoituksia ajavaa diskurssia myös haastettiin eduskunnan kyselytunneilla (esim. PTK 4/2017 vp), mutta sen tehokkuus näkyi kahdessa eduskunnan hyväksymässä kaksoiskansalaisuutta turvallistavassa lakipaketissa (EV 122/2017 vp; EV 280/2018 vp).

Suhteessa kaksoiskansalaisuuskysymykseen Jussi Niinistön taustassa vaikuttavat kansalliskonservatiiviset arvot. Perussuomalaisten, joiden jäsen hän oli kesäkuuhun 2017 asti, maahanmuuttopoliittisessa ohjelmassa vuonna 2015 kirjattiin tavoite tiukentaa kansalaisuuden ja kaksoiskansalaisuuden myöntämisen ehtoja. Tämän mukaisesti kansalaisuutta ei pitäisi 
hyväksyä matkustamista helpottamaan, vaan sen tulisi heijastaa hakijan "sitoutuneisuutta" uuteen kotimaahansa. Kaksoiskansalaisuudesta viitattiin voivan kehittyä strateginen turvallisuusriski, mikäli "jokin ulkovalta katsoo Suomessa asuvien kansalaistensa kuuluvan omaan legitiimiin vaikutuspiiriinsä”. (Perussuomalaiset 2015, 5-6.) Ennen aikaansa puolustusministerinä Niinistö on toiminut konservatiivisen kansallisen identiteetin ja maanpuolustuksen ympärille profiloituneissa järjestöissä, kuten Suomalaisuuden liitossa, Sotilasperinteen seurassa ja Maanpuolustustiedotuksen suunnittelukunnassa. Hän on myös kirjoittanut väitöskirjan ja julkaissut muuta kirjallisuutta kansallismielisen toiminnan historian aihepiireihin liittyen. (Jussiniinisto.fi 2019.)

Blogikirjoituksista ensimmäinen, 3.11.2016 julkaistu kirjoitus pohjautuu Suojelupoliisin eduskunnalle 27.9. turvallisuuspoliittista selontekoa varten antamaan lausuntoon (EDK-2016AK-75745). Tästä puolustusministeri nostaa esiin kaksoiskansalaisuutta ja ulkomaalaisten kiinteistö- ja maakauppoja käsittelevät kohdat. Jälkimmäiseen liittyen Supon lausunto varoittaa näiden tilojen mahdollisesta käytöstä tunnuksettomien joukkojen majoituspaikkoina. Niinistö (2016) huomauttaa kyseisen asian olleen viime aikoina julkisuudessa liitetty etenkin venäläisiin, mutta ei itse avaa tätä näkökulmaa enempää. Käsiteltävän asian liittäminen julkiseen keskusteluun on blogikirjoituksille tavanomaista, mutta tässä tapauksessa asian liittyminen juuri venäläisiin toisintuu sen sijaan, että kaksoiskansalaisuus esitettäisiin yleisenä periaatekysymyksenä.

Supon lausunnon mukaan Suomeen kohdistuva ulkomaantiedustelu on huomattavaa tietojen hankinnassa sekä yleiseen mielipiteeseen ja suoran päätöksenteon kannalta merkittäviin henkilöihin kohdistuvassa vaikuttamisessa. Yksittäisiin Suomeen vaikuttaviin valtioihin viitataan esimerkissä kaksoiskansalaisuuden merkityksellisyydestä: "Esimerkiksi kaikki Venäjän kansalaiset ovat kaksoiskansalaisuudesta riippumatta Venäjän lakien mukaan velvoitettuja auttamaan Venäjän turvallisuusviranomaisia" (EDK-2016-AK-75745, s. 3). Mainittuja lakeja ei spesifioida, mutta tämän tiedon merkitys korostuu myös puolustusministerin myöhemmässä argumentaatiossa lojaliteettiristiriidoista. Vaikka lausunnon toimenpidekehotuksen keskiössä on virka-asia sekä maa- ja kiinteistökaupat, sen tuottaman tiedon perusteella turvallistamista voi ulottaa laajemminkin Venäjän kansalaisiin.

Blogikirjoituksensa lopuksi Niinistö (2016) mainitsee Valtiovarainministeriön (2015) asettaman työryhmän tekemän selvityksen "Kaksoiskansalaisuus valtion virkaan nimitettäessä", jossa selvitettiin aiheeseen liittyvää nykyistä lainsäädäntöä ja kansainvälisiä velvoitteita. Hän kertoo puolustushallinnon kannattavan selvityksen antamaa suositusta päivittää virkamieslakia liittyen virkoihin, jotka edellyttävät Suomen kansalaisuutta ja turvallisuusselvitystä. Esimerkkinä turvallisuussyystä puolustusministeri mainitsee upseerin virassa olevalle kaksoiskansalaiselle koituvat lojaliteettiristiriidat. Valtiovarainministeriön $(2015,9,35)$ selvityksessä lojaliteettihuolella tarkennetaan viitattavan tehtäviin, joissa virkamiehen kotivaltioiden valtiolliset edut ovat vastakkain, jolloin kaksoiskansalaisuus voisi muodostua uhkatekijäksi.

Puolustusministerin esille nostama suositus on yksi Valtiovarainministeriön (emt., 37-38.) selvityksessä annetuista politiikkasuosituksista. Selvitys liittää tämän vaihtoehdon haasteet perustuslain ja kansainvälisten sopimusten velvoitteisiin. Niinistön mainitsematta jättämiin vaihtoehtoihin lukeutuvat EU-kansalaisten jättäminen virkarajoituksen ulkopuolelle, virkaan nimitettävälle tehtävän turvallisuusselvityksen kehittäminen sekä päivitys toiseen valtioon liittyvien sidonnaisuuksien vaikuttamisesta nimitykseen. Myöhemmin eduskunta hyväksyi lakimuutokset kahden viimeksi mainitun ehdotuksen perusteella vuosina 2017 ja 2019 (EV 122/2017 vp; EV 280/2018 vp). 
Toisessa blogikirjoituksessa Niinistö (2017) käsittelee Ylen uutisointia (esim. Happonen 2017a; 2017b; 2017c) Suomi-Venäjä -kaksoiskansalaisten syrjinnästä Puolustusvoimissa, minkä hän kiistää. Hän toteaa yksittäistapaukset kuitenkin mahdollisiksi, mutta etteivät ne ole hyväksyttyjä. Niinistö (2017) kirjoittaa syrjintäväitteiden levinneen venäläismedioissa, joissa asia on esitetty kuvastavan Suomen Venäjän-vastaisuutta. Tämän jälkeen hän perustelee kansalaisuuslainsäädännön muuttamista uudella kansainvälisellä tilanteella, mahdollisilla lojaliteettiristiriidoilla sekä asiaan liittyvillä Venäjän oikeusnormeilla. Kyseisen 8.2. julkaistun blogikirjoituksen lainsäädännön muutosta koskeva sisältö on yhtenäinen sisäministeriön ja puolustusministeriön samana päivänä antaman muutoshankkeen asettamispäätöksen kanssa (EDK-2017-AK-107711, kts. lainaus tämän artikkelin alussa).

Niinistö (2017) kertoo, että kaksoiskansalaisia työskentelee Puolustusvoimissa, ja että Puolustusvoimat on hiljattain tehnyt sisäisen tutkimuksen osoituksena toiminnan lainmukaisuudesta huolehtimisesta (Pääesikunta 2017). Puolustusministeri kuitenkin korostaa tarvetta lakien päivittämiseen ja perustelee sitä maailman merkittävällä muuttumisella sen jälkeen, kun eduskunta päätti monikansalaisuuden sallivasta kansalaisuuslaista vuonna 2003 (EV 253/2002 vp). Näyttönä muuttuneesta maailmasta Niinistö mainitsee Venäjän lainsäädännön muutokset ja kansalaisiltaan vaatiman täydellisen lojaliteetin, joka voi aiheuttaa kaksoiskansalaisille intressiristiriitoja sekä altistaa heidät ja heidän perheensä ulkoiselle painostukselle. Maininta Venäjän laeista viittaa ilmeisesti Niinistön aiemmassa blogissa käsittelemään Supon lausuntoon (EDK-2016-AK-75745), jossa ei tosin kerrota Venäjän edellyttävän kansalaisiltaan ehdotonta lojaliteettia, vaan velvoituksesta auttaa turvallisuuspalveluita. Puolustusministerin mukaan kaksoiskansalaisten sulkeminen sotilasviroista on kansallisen turvallisuuden kannalta erittäin painavasti perusteltua perustuen lain hallinnon virkamiehiltä edellyttämään ehdottomaan lojaaliuteen Suomen valtiota kohtaan sekä virkoihin liittyvän salaisen tiedon turvaamiseen.

Venäjän erityisasema päätöksentekoon vaikuttavissa kansainvälisissä olosuhteissa on oleellinen myös vuosien 2016 ja 2017 Suomen turvallisuuspoliittisissa selonteoissa. Vaikka Suomen lähialueen jännitteisyyden syitä kuvataan niissä melko varovaisesti, on perusasetelma selkeä: Suomi tekee yhteistyötä läntisessä yhteisössä, jonka näkemys ja tavoitteet kansainvälisessä järjestelmässä ovat osittain vastakkaisia Venäjän kanssa. (Valtioneuvoston kanslia 2016, 13-14; 2017, 8-10.)

Niinistön mainitseman vuoden 2003 kansalaisuuslain valmisteluissa huomioitiin kansalaistettavien mahdolliset sidonnaisuus- ja lojaliteettiristiriidat ja heihin kohdistuvat toisten valtioiden vaikuttamispyrkimykset. Näille huolille ei kuitenkaan annettu päätöksenteossa yhtä paljon painoarvoa kuin tarpeelle turvata yksilöiden sosiaaliset ja taloudelliset turvallisuustarpeet, maahanmuuttajien kotoutumisen ja heidän (sekä ulkosuomalaisten) taloudellisten voimavarojen hyödyntämisen. Lisäksi kansalaisuuden merkityksen katsottiin yleisesti vähentyneen. (HE 235 2002.) Tämän lain lakialoitteessa kaksoiskansalaisuuteen liittyvien turvallisuusuhkien viitattiin olevan pätemättömiä kansainvälistyvässä maailmassa (LA 18011999 vp). Puolustusministeriön ja sisäministeriön aloite EDK-2017-AK-107711 ei käsittele kaksoiskansalaisuutta samalla tavalla monipuolisena kysymyksenä, vaan ohittaa muut argumentit valtion välttämättömään (informaatio)turvallisuuteen vetoamalla, siis turvallistamalla.

Tyytymättömyys vuoden 2018 alusta voimaan tulleen uuden turvallisuusselvityslain (ks. EV 1222017 vp) riittävyyteen vastata ulkomaansidonnaisuuksien turvallisuusriskeihin näkyi siinä, että puolustusministeri Niinistö ei edes maininnut näitä uudistuksia aiheeseen 
liittyvissä blogeissaan. Tämä osoittaa pyrkimystä ryhmäperusteisiin turvallisuuskriteereihin yksilökohtaisuuden sijaan. Niinistön (2018a) blogi 8.3. käsitteli tapaamista politiikan toimittajien kanssa. Puheenaiheiden joukosta puolustusministeri nosti esiin kaksoiskansalaisuuden turvallisuushallinnon viroissa, joka oli tuolloin lähtenyt juuri lausuntokierrokselle. Hän toisti kansallisen turvallisuuden vaatiman tarpeen muuttaa lainsäädäntöä estämällä kaksoiskansalaisten pääsy sotilasvirkoihin hallitusohjelman mukaisesti. Mahdollisuuden poikkeuksille puolustusministeri kuitenkin säilyttäisi. Kaksoiskansalaisen siteet toiseen kotimaahansa, jotka eivät voi aiheuttaa kansallisen turvallisuuden kannalta kestämätöntä lojaliteettiristiriitaa, määrittyvät tämän lausunnon mukaan poikkeuksiksi.

Niinistön (2018b) blogi 10.9. pohjautuu hänen maanpuolustuskurssin avajaisissa pitämäänsä puheeseen. Hän kertoo kaksoiskansalaisuuslakiesityksen sekä ulkomaalaisten kiinteistöjen omistamista ohjaavan lakihankkeen olevan esimerkkejä ajankohtaisista lainsäädäntöhankkeista, joita tehdään osana kokonaismaanpuolustuksen inventaariota. Näihin aloitteisiin liittyen Niinistö tarkentaa, että toimenpiteet tehdään "puuttuen mahdollisimman vähän" ulkomaalaisten mahdollisuuteen investoida Suomeen ja perusoikeuksien suojaan. Puolustusministerin mainitsemassa Sipilän hallituksen ohjelmassa kaksoiskansalaisuuteen liittyvää lainsäädäntöä linjataan tarkennettavan kokonaisturvallisuuden vahvistamista varten niin, että valmistelun yhteydessä "kiinnitetään huomiota perus- ja ihmisoikeuksien toteuttamiseen" (Valtioneuvoston kanslia 2015, 35). Nyt puolustusministerin puheen sanavalinta "puuttuminen" esittää, etteivät perusoikeudet välttämättä säily koskemattomina virkarajoitusten vaatimuksen edessä. Toisaalta kuitenkin juuri voimaan tulleen turvallisuusselvityslain voi tulkita vastaavan hallitusohjelmaa vastaten Valtionvarainministeriön (2015, 38-39) työryhmän toimenpide-ehdotusta selventää aiempaa paremmin valtion virkoihin hakeutuvien ulkomaansidonnaisuuksia tehtävä- ja hakijakohtaisesti.

Edellä mainitut kaksi hanketta kytkeytyvät kokonaisturvallisuuden toimintamalliin jo hallitusohjelmassa (Valtioneuvoston kanslia 2015, 35). Kokonaisturvallisuudella tarkoitetaan valtion itsenäisyyteen, väestön elinmahdollisuuksiin liittyvien ja muiden yhteiskunnan elintärkeiden toimintojen turvaamista (Valtioneuvosto 2012, 18). Kokonaisturvallisuuden toimintamallia on kritisoitu sen lineaarisesta lähestymistavasta ja kyvyttömyydestä vastata monimuotoisesti verkostoituneen ja globalisoituneen todellisuuden haasteisiin. Tällä perusteella sitä on suositeltu laajentamaan yhteistoimintamalliksi, jossa viranomaiset, elinkeinoelämä, järjestöt ja kansalaiset otetaan mukaan yhteiskunnallisen turvallisuuden luomisessa ja varautumisessa uhkiin (Keskinen et al. 2017; Turvallisuuskomitea 2017). Kaksoiskansalaisuuteen liittyneen lakihankeen mietinnöt perustuslakivaliokunnalta ja hallintovaliokunnalta eivät kuitenkaan osallistaneet yhteiskunnallisia toimijoita järjestöpuolelta (PuVM 7/2018 vp).

Puolitoista kuukautta ennen hallituksen eduskunnalle antamaa lakiesitystä Niinistö (2018c) kertoo blogissaan 2.10. uudesta laista, joka kieltäisi kaksoiskansalaisten pääsyn Maanpuolustuskorkeakouluun sekä Puolustusvoimien sotilasvirkoihin Rajavartiolaitoksen virkoihin. Upseeriksi pääsy olisi Niinistön mukaan edelleen mahdollista Suomen ja Ruotsin kaltaisten demokraattisten maiden kaksoiskansalaisille. Tämä blogipäivitys perustuu erityisesti Niinistön antamaan haastatteluun MTV:n (2018) televisiouutislähetyksessä, missä hän käsittelee lakialoitteen lisäksi julkisuuteen tulleita erimielisyyksiään sisäministeri Kai Mykkäsen kanssa. Toisin kuin puolustusministeriön valmistelemassa lakiesityksessä, Mykkänen oli hieman aiemmin ilmoittanut nykyisen muotoisen turvallisuusselvityksen riittävän sisäministeriön alaisessa Rajavartiostossa. Puolustusministeri huomauttaa Rajavartiolaitoksen upseereiden tulevan joka tapauksessa uudistuksen piiriin, koska niihin valmistutaan Maanpuolustuskorke- 
akoulusta. Niinistö kuitenkin korosti harmistustansa liittyen Mykkäsen kannan vaihtumiseen prosessin aikana.

Turvallistava diskurssi ilmenee asian esittämisessä kyseenalaistamattomana välttämättömyytenä. Kaksoiskansalaisten kategorinen sulkeminen sotilasviroista pyritään erottamaan poliittiseen päätöksentekoon kuuluvasta asioiden kriittisesti arvioivasta keskustelusta, missä uusi tieto voi vaikuttaa päätökseen. Myöhemmin eduskunnan päätös tiukentaa virkakelpoisuusehtoja viroissa, joihin lain mukaan vaaditaan yksinomainen Suomen kansalaisuus, kaventaa käytettyjen määritelmien kautta täysivaltaisen kansalaisuuden kattavuutta kaksoiskansalaisilta. Samalla on luotu mahdollisuus tulkita ihmisten kaksoiskansalaisuutta niin, että etusijalle nostetaan toinen, ei Suomen kansalaisuus. Tähän liittyen Audrey Macklin (2007) on kirjoittanut siitä, kuinka ryhmien esittäminen "ulkomaalaisena" helpottaa valtion omien kansalaisten kansalaisoikeuksia rikkovaa kansallisen turvallisuuden edistämistä. Turvallisten ja ei-turvallisten valtioiden määrittäminen määrää uuden lain diskurssissa paitsi vaarallisia ulkomaita, samalla myös omia kansalaisia, joilla on näihin valtioihin ulkomaansidonnaisuuksia.

\section{"Puun ja kuoren välissä": kaksoisturvallistetut}

Tässä artikkelissa olemme tarkastelleet kaksoiskansalaisuuden ja ylirajaisten suhteiden turvallistamista Suomessa ja Venäjällä siitä näkökulmasta, miten se asiakirjojen ja lausuntojen kautta havainnollistaa ja luo käsityksiä venäläisistä, joilla on ulkomaansidonnaisuuksia. Samalla olemme hahmottaneet Suomessa asuviin venäjänkielisiin vaikuttavia diskursseja, joita johdannossa viittaamamme aiemman tutkimuksen valossa olemme luonnehtineet "puun ja kuoren väliin" joutumiseksi. Käsittelemämme aineisto ei kuitenkaan yksinään kerro kyseisten prosessien vaikutuksesta itse kaksoiskansalaisiin ja henkilöihin, joilla on muita ulkomaansidonnaisuuksia. Jatkotutkimuksen kannalta onkin erittäin tärkeää tarkastella turvallistamisen vaikutuksia antamalla ääni heidän kokemuksilleen ja näkemyksilleen.

Venäjällä kaksoiskansalaisuuden ja ulkomaansiteiden turvallistaminen on ollut järjestelmällistä ja jatkunut koko 2000-luvun, päätyen kaksoiskansalaisuudesta ja oleskeluluvista viranomaisille ilmoittamisvelvollisuuden säätämiseen. Tätä voi tulkita eksplisiittisenä epäluottamuksen eleenä niin ulkomaita kuin niihin jossakin suhteessa olevia kansalaisia kohtaan maan hallinnolta, joka samalla vaatii heiltä erityistä lojaalisuutta diaspora- ja identiteettipolitiikoissa. On ilmeistä, että inhimillisen turvallisuuden näkökulmat olivat myös Venäjän valtion lainsäädäntötyössä valtion turvallisuudelle alistettavassa suhteessa.

Muutoinkin kuin kysymys kansalaisuuksista sotilasviroissa, vuosina 2017-2019 Suomen päivitetyissä laeissa tunnistetun turvallisuusuhkan liittäminen ulkomaansidonnaisuuksiin luo laajasti sovellettavissa olevaa tietoa siitä, kuinka ihmisen ylirajaiset siteet tulisi arvioida turvallisuusnäkökulmasta. Niin kutsutun pehmeän turvallisuuden puolet, taloudelliset mahdollisuudet, sosiaalinen kollektiivinen identiteetti, kulttuurin ylläpito, yksilön oikeudet, koheesio, poliittinen osallisuus ja edustetuksi tuleminen voidaan tulkita kovan valtiollisen turvallisuuden riskeiksi. Muutokset edistävät käsitystä yhteiskunnallisista olosuhteista, joissa venäläiset ulkomaansidonnaisuudet ovat nollasummapelissä valtioiden kansallista turvallisuutta vastaan. Tämän perusteella Venäjään sidoksissa olevien Suomen kansalaisten yhdenvertaisuuden heikentäminen tietyissä yhteiskunnallisissa tehtävissä toimiessa asemoidaan kelpoisuuden osalta vähäisenä uhrauksena kansallisen edun puolesta. Huomattavaa on, että samanaikaisesti näiden lakipakettien valmistamisen kanssa oli yhteiskunnan kokonaisturvallisuuteen päätöksentekijöille tarjottu yhteistoimintamallia vastauksena jo aiemmin liian 
kapea-alaiseksi ja valtiokeskeiseksi tunnistetun turvallisuuspolitiikan kritiikkiin (Keskinen et al. 2017; Turvallisuuskomitea 2017).

Kaksoiskansalaisten virkakelpoisuusrajoituksia ajaneessa aloitteessa ei korostettu Venäjän tai venäläisyyden merkitystä turvallisuusuhkan kannalta, vaan määreitä käytettiin esimerkkeinä kansallisen turvallisuuden ja kansainvälisten olosuhteiden yhtälössä, jonka logiikalla turvallisuusuhkaa perusteltiin. "Naapuria" kohti osoitetun välttelyn voidaan väittää olevan osa Suomen virallista ja perinteistä ulko- ja turvallisuuspoliittista puhetapaa. Vaikka aiheen Venäjä-aspektin julkituominen on mahdollista tehdä tarkoituksena_estää syrjintää tai edistää politiikan läpinäkyvyyttä, se voi myös kääntyä haitalliseksi ja vahvistaa ihmisiin liitettyä turvallisuusuhan leimaa. Tämän vuoksi aiheesta tulee kirjoittaa ja esittää lausuntoja erityisellä herkkyydellä. Venäjän maanmiespolitiikka, lainsäädäntö ja tunnuksettomiin joukkoihin liitetyt maakauppojen riskit liitettiin Suomessa tähän kysymykseen lainsäädäntöprosessin aikana niin journalistien ja tutkijoiden kuin myös politiikan tekijöiden taholta.

\section{Lähteet}

\section{Lain valmistelu, laki- ja eduskunta-asiakirjat}

Cikrf.ru, Statja 29. Status tšlenov komissii. http://www.cikrf.ru/law/federal_law/comment/st29.php (Tarkistettu 2.10.2019).

EDK-2016-AK-75745, Suojelupoliisin lausunto ulko- ja turvallisuuspoliittiseen sekä sisäisen turvallisuuden selontekoihin liittyen. 27.9.2016. https://www.eduskunta.fi/FI/vaski/JulkaisuMetatieto/ Documents/EDK-2016-AK-75745.pdf?fbclid=IwAR3_9rlUC9E8D8BELF23d7HDcnIWdjDQW jPs14WPNLUYe0T1YKpyi7vNLjY. (Tarkistettu 29.9.2019)

EDK-2017-AK-107711, Puolustusministeriön hankkeen asettamispäätös koskien puolustusvoimista annetun lain ja Maanpuolustuskorkeakoulusta annetun lain muuttamista. 1.2.2017. https://www. eduskunta.fi/FI/vaski/JulkaisuMetatieto/Documents/EDK-2017-AK-107711.pdf (Tarkistettu 29.9.2019)

EV 253/2002 vp, Eduskunnan vastaus. 23.4.2003. https://www.eduskunta.fi/FI/vaski/EduskunnanVastaus/Documents/ev_253+2002.pdf (Tarkistettu 29.9.2019)

EV 122/2017 vp, Eduskunnan vastaus. 21.11.2017. https://www.eduskunta.fi/FI/vaski/EduskunnanVastaus/Documents/EV_122+2017.pdf (Tarkistettu 29.9.2019)

EV 280/2018 vp, Eduskunnan vastaus. 5.3.2019. https://www.eduskunta.fi/FI/vaski/EduskunnanVastaus/Documents/EV_280+2018.pdf (Tarkistettu 29.9.2019)

KRF (2019) Konstitutsija Rossijskoj Federatsii, Statja 62. http://constitution.kremlin.ru/ (Tarkistettu 29.9.2019)

N 62-FZ, Federalnyi zakon ot 31 maja 2002 g. "O Graždanstve Rossijskoi Federatsii”. Rossijskaja gazeta 5.6.2002 https://rg.ru/2002/06/05/zakon-gragdan.html (Tarkistettu 29.9.2019)

N 79-FZ [27.7.2004], Federalnyi zakon ot 27 ijulja 2004 g. "O gosudarstvennoi graždanskoi službe Rossijskoi Federatsii”. Rossijskaja gazeta, 31.7.2004. https://rg.ru/2004/07/31/gossluzhba-dok. html (Tarkistettu 29.9.2019)

N 79-FZ [7.5.2013], Federalnyi zakon ot 7 maja 2013 g. N 79-FZ “O zaprete otdelnym kategorijam lits otkryvat i imet stšeta (vklady), hranit nalitšnyje denežnye sredstva i tsennosti v inostrannyh 
bankah, raspoložennyh za predelami territorii Rossijskoi Federatsii, vladet i (ili) polzovatsja inostrannymi finansovymi instrumentami”. Rossijskaja gazeta 14.5.2013. https://rg.ru/2013/05/14/ zapret-dok.html (Tarkistettu 29.9.2019)

N 128-FZ, Federalnyi zakon ot 25.07.2006 g. O vnesenii izmenenij v otdelnyje zakonodatelnye akty Rossijskoi Federatsii v tšasti utotšnenija trebovanij k zameštšeniju gosudarstvennyh i munitsipalnyh dolžnostei. http://www.kremlin.ru/acts/bank/24096 (Tarkistettu 29.9.2019)

N 142-FZ, Federalnyi zakon ot 4 ijunja 2014 g. "O vnesenii izmenenij v statji 6 b 30 Federalnogo zakona "O graždanstve Rossijskoi Federatsii" i otdelnye zakonodatelnye akty Rossijskoi Federatsii". Rossijskaja gazeta 6.06.2014. https://rg.ru/2014/06/06/grajdanstvo-dok.html (Tarkistettu 29.9.2019)

N 256-FZ, Federalnyi zakon ot 29 dekabrja 2006 g. (red. Ot 02.08.2019) "O dopolnitelnyh merah gosudarstvennoi poddrežki semei, imejuštših detei”. http://www.pfrf.ru/info/order/mother_fam_capital 1589 (Tarkistettu 29.9.2019)

N 305-FZ, Federalnyi zakon ot 14 oktjabrja 2014 g. "O vnesenii izmenenij v Zakon Rossijskoi Federatsii “O sredstvah masovoi informatsii”. Rossijskaja gazeta 17.10.2014. https://rg.ru/2014/10/17/ ino-smi-dok.html (Tarkistettu 29.9.2019)

HE 235/2002, Hallituksen esitys Eduskunnalle ulkomaalaislaiksi ja eräiksi siihen liittyviksi laeiksi. 20.12.2002. https://www.eduskunta.fi/FI/vaski/HallituksenEsitys/Documents/he_265+2002.pdf (Tarkistettu 29.9.2019)

LA 18011999 vp, Laki kansalaisuuslain muuttamisesta. 3.11.1999. https://www.eduskunta.fi/FI/vaski/ Lakialoite/Documents/la_180+1999.pdf (Tarkistettu 29.9.2019)

PTK 4/2017 vp, Eduskunnan täysistunnon pöytäkirja 9.2.2017. https://www.eduskunta.fi/FI/vaski/ Poytakirja/Documents/PTK_4+2017.pdf (Tarkistettu 29.9.2019)

PuVM 7/2018 vp, Puolustusvaliokunnan mietintö. 22.2.2019 https://www.eduskunta.fi/FI/vaski/ Mietinto/Documents/PuVM_7+2018.pdf (Tarkistettu 29.9.2019)

Pääesikunta (2017), Puolustusvoimat selvitti kaksoiskansalaisuuteen liittyvät käytännöt. 8.2. https:// puolustusvoimat.fi/artikkeli/-/asset_publisher/puolustusvoimat-selvitti-kaksoiskansalaisuuteenliittyvat-kaytannot. (Tarkistettu 29.9.2019)

Turvallisuuskomitea (2017), Yhteiskunnan turvallisuusstrategia. Valtioneuvoston Periaatepäätös 2.11.2017.

Valtioneuvosto (2012), Valtioneuvoston periaatepäätös kokonaisturvallisuudesta 5.12. Helsinki: Valtioneuvosto. https://www.defmin.fi/files/3023/Periaatepaatos_kokonaisturvallisuudesta_2012_fi.pdf. (Tarkistettu 29.9.2019)

Valtioneuvoston kanslia (2015), Ratkaisujen Suomi: Pääministeri Juha Sipilän hallituksen strateginen ohjelma 29.5. Hallituksen julkaisusarja 10/2015. https://valtioneuvosto.fi/documents/10184/1427398/Ratkaisujen+Suomi_FI_YHDISTETTY_netti.pdf. (Tarkistettu 29.9.2019)

Valtioneuvoston kanslia (2016), Valtioneuvoston ulko-ja turvallisuuspoliittinen selonteko. VNS 6/2016 vp. Valtioneuvoston kanslia, Helsinki https://um.fi/documents/35732/48132/hallituksen_ulko_ja turvallisuuspoliittinen_selonteko/0ff430d7-5ced-4d38-3606-e2349f1b58b5?t=15258661481120. (Tarkistettu 29.9.2019)

Valtioneuvoston kanslia (2017), Valtioneuvoston puolustusselonteko. VNS 5/2017 vp., Helsinki. https:// www.defmin.fi/files/3683/J05_2017_VN_puolustusselonteko_Su_PLM.pdf. (Tarkistettu 29.9.2019)

Valtiovarainministeriö (2015), Kaksoiskansalaisuus valtion virkaan nimitettäessä. Valtiovarainministeriön julkaisu - 26/2015. www.vm.fi/julkaisut.

\section{Kirjallisuus}

Aksenov, Artemi (2014), Dvoinoje graždanstvo i problemy natsionalnoi bezopasnosti: rossijskoje zakonodatelstvo i zarubežnaja praktika. - Vestnik ekonomiki, prava i sotsiologii 2014:4, 115-119.

Alikina, Ekaterina, Stognei, Anastasija (2016), Otšhjot pošjol: stoit li soobštšat gosudarstvu o svojem stšjote za rubežom? 18.5. https://www.rbc.ru/money/18/05/2016/573b64499a7947c95a528d6d.

Bauböck Rainer (2019), Genuine Links and Useful Passports: Evaluating Strategic Uses of Citizenship. - Journal of Ethnic and Migration Studies 45:6, 1015-1026. https://doi.org/10.1080/13691 83X.2018.1440495.

Bauböck, Rainer (2007), The Trade-off Between Transnational Citizenship and Political Autonomy. Dual Citizenship in Global Perspective: From Unitary to Multiple Citizenship. Ed. Thomas Faist, Peter Kivisto. New York: Palgrave Macmillan, 69-91. 
Benhabib, Seyla, Post, Robert (2006), Another cosmopolitanism. Oxford University Press.

Buzan, Barry, Hansen, Lene (2009), The Evolution of International Security Studies. Cambridge University Press. https://doi.org/10.1017/CBO9780511817762.

Byford, Andy (2012), The Russian Diaspora in International Relations: 'Compatriots' in Britain. Europe-Asia Studies 64:4, 715-735. DOI: 10.1080/09668136.2012.660764.

Campbell, David (1998), Writing security: United States foreign policy and the politics of identity. University of Minnesota Press.

Davydova, Olga (2009), Suomalaisena, venäläisenä ja kolmantena: etnisyysdiskursseja transnationaalissa tilassa. Joensuu: Joensuun yliopisto.

Davydova-Minguet, Olga, Sotkasiira, Tiina, Oivo, Teemu, Riiheläinen, Janne (2016), Suomen venäjänkieliset mediankäyttäjinä. Valtioneuvoston selvitys- ja tutkimustoiminnan julkaisusarja 35/2016.

Davydova-Minguet, Olga (2014), Diaspora käytännön kategoriana. - Idäntutkimus 4/2014. 44-62.

Davydova-Minguet, Olga (2018), Media, Memory, and Diaspora Politics in Transnational Public Spheres. - Post-Cold War Borders: Reframing Political Space in Eastern Europe. Eds. Laine, Jussi, Liikanen, Ilkka, Scott, James W. London: Routledge, 93-111.

Davydova-Minguet, Olga, Pöllänen, Pirjo (2018), Hyvinvointi rajaseudulla asuvien venäläisten maahanmuuttajanaisten arjessa. - Maahanmuutto, palvelut ja hyvinvointi. Kohtaamisissa kehittyviä käytäntöjä. Toim. Johanna Hiitola, Merja Anis, Kati Turtiainen. Tampere: Vastapaino. 169-188.

Délano Alonso, Alexandra, Mylonas, Harry (2019), The Microfoundations of Diaspora Politics: Unpacking the State and Disaggregating the Diaspora. - Journal of Ethnic and Migration Studies, Vol. 45:4, 473-491. DOI: 10.1080/1369183X.2017.1409160.

Demoscope (2014), Gazety pišut o dvoinom i “spjaštšem” graždanstve. - Demoscope.ru http://www. demoscope.ru/weekly/2014/0599/gazeta026.php. (Tarkistettu 29.9.2019)

Faist, Thomas (2007), Introduction: The Shifting Boundaries of the Political. - Dual Citizenship in Global Perspective: From Unitary to Multiple Citizenship. Eds. Thomas Faist, Peter Kivisto. New York: Palgrave Macmillan, 1-23.

Gamlen, Alan (2006), Diaspora Engagement Policies: What are they, and what kinds of states use them? Centre on Migration, Policy and Society, Working Paper No. 32. University of Oxford.

Grigas, Agnia (2016), Beyond Crimea. The New Russian Empire. New Haven \& London: Yale University Press.

Happonen, Päivi (2017a), Puolustusvoimat laittoi Venäjän kaksoiskansalaiset erityistarkkailuun myös varusmiesten toimintaa on alettu rajoittaa. - Yle uutiset 31.1. https://yle.fi/uutiset/3-9433295.

Happonen, Päivi (2017b), Analyysi: Mitä Suomen ja Venäjän kaksoiskansalaisille pitäisi tehdä? - Yle uutiset 31.1. https://yle.fi/uutiset/3-9433863. (Tarkistettu 29.9.2019)

Happonen, Päivi (2017c), Kaksoiskansalaisia koskeva ohjeistus tulee Puolustusvoimien tiedustelulaitokselta. - Yle uutiset 8.2. https://yle.fi/uutiset/3-9448724. (Tarkistettu 29.9.2019)

Heino, Eveliina (2018), Yhteiskunnan Jäsenyyden Ehdot: Arjen kansalaisuuden rakentaminen ja peruspalvelukokemukset venäläistaustaisten perheiden kertomuksissa. Helsinki: Helsingin yliopisto.

Jussiniinisto.fi (2019), CV. - jussiniinisto. $f<<$ https://jussiniinisto.fi/index.php/esittely/cv/>. (Tarkistettu 29.9.2019)

Kananen, Marko, Ronkainen, Jussi, Saari, Kari (2018), Kansallisuusorientaatiot - nuorten SuomiVenäjä -kaksoiskansalaisten yhteiskunnalliset ja ylirajaiset siteet. - Yhteiskuntapolitiikka 83:5-6, 518-531.

Keskinen Marko, Kantola Arttu, Mäkinen Juha \& Salonen Arto O. (2017), Miten yhteiskehittää kokonaisturvallisuutta? Tieteidenvälisiä näkemyksiä Winland-hankkeesta. - Tiede ja Ase, 75. https:// journal.fi/ta/article/view/67728. (Tarkistettu 29.9.2019)

Kinnvall, Catarina (2004), Globalization and Religious Nationalism: Self, Identity, and the Search for Ontological Security. - Political Psychology 25:5, 741-767.

Kokkonen, Tuomo (2016), Sosiaalinen kansalaisuus kehittyvässä yhteiskunnassa. T.H. Marshallin sosiaalisia oikeuksia korostava kansalaisuuskäsitys hyvinvointivaltiota koskevan keskustelun innoittajana. Jyväskylä: University of Jyväskylä.

Kolesnikov, Andrei (2014), Bolšoj bratan smotrit za toboj. - Novaja gazeta 31.3. https://www.novayagazeta.ru/articles/2014/03/31/58973-bolshoy-bratan-smotrit-za-toboy. (Tarkistettu 29.9.2019)

Kuivaniemi, Olli (2018), Porua aiheuttanut kaksoiskansalaisuusmuutos etenee - Ministeri Niinistö: Poikkeuksia voidaan tehdä. - Keskisuomalainen 8.2. https://www.ksml.fi/kotimaa/Porua-aiheuttanut-kaksoiskansalaisuusmuutos-etenee-\%E2\%80\%93-Ministeri-Niinist\%C3\%B6-Poikkeuksia- 
voidaan-tehd\%C3\%A4/1119940. (Tarkistettu 29.9.2019)

Lepola, Outi (2000), Ulkomaalaisesta suomenmaalaiseksi. Monikulttuurisuus, kansalaisuus ja suomalaisuus maahanmuuttopoliittisessa keskustelussa. Helsinki: Suomalaisen Kirjallisuuden Seura.

Lindqvist, Olli (2014), Suomi harkitsee tiukennuksia kaksoiskansalaisuuteen. - Yle uutiset 21.8. https:// yle.fi/uutiset/3-7425497. (Tarkistettu 29.9.2019)

Longo, Matthew (2018), The Politics of Borders: Sovereignty, Security and the Citizen after 9/11. Cambridge: Cambridge University Press

Lähteenmäki, Mika (2015), Kieli-ideologia ja kielipolitiikka Venäjän valtion yhtenäisyyden rakentajina. -Idäntutkimus 1/2015, 26-35.

Macklin, Audrey (2007), The Securitization of Dual Citizenship. - Dual Citizenship in Global Perspective: From Unitary to Multiple Citizenship. Eds. Thomas Faist, Peter Kivisto. New York: Palgrave Macmillan, 42-66.

Makarychev, Andrey, Yatsyk, Alexandra (2017), Biopower and Geopolitics as Russia's Neighborhood Strategies: Reconnecting People or Reaggregating Lands? - Nationalities Papers, 45:1, 25-40.

Marshal, Thomas Humphrey (1950), Citizenship and Social Class. Cambridge: Cambridge University Press.

Meduza.io (2014), Za sokrytije dvoinogo graždanstva oshtrafovany 43 tysjatši tšelovek. Meduza, 5.12. https://meduza.io/news/2014/12/05/za-sokrytie-dvoynogo-grazhdanstva-oshtrafovany-43-tysyachichelovek. (Tarkistettu 29.9.2019)

Mentzelopoulou, Maria Margarita, Dumbrava, Costica (2018), Acquisition and Loss of Citizenship in EU Member States Key Trends and Issues. European Parliamentary Research Service PE625. 116 July 2018.

Mouffe, Chantal (1988), The Civics Lesson. - New Statesman and Society Oct 7, 1988, 28-31.

MTV (2018), Jussi Niinistö: Kaksoiskansalaiset pääsevät sittenkin sotilasvirkoihin myös jatkossa - erivapaus heltiää kuitenkin vain, jos olet kotoisin "demokraattisesta oikeusvaltiosta". - MTV uutiset 29.9. https://www.mtvuutiset.fi/artikkeli/jussi-niinisto-kaksoiskansalaiset-paasevat-sittenkinsotilasvirkoihin-myos-jatkossa-erivapaus-heltiaa-kuitenkin-vain-jos-olet-kotoisin-demokraattisestaoikeusvaltiosta/7092830\#gs.abxc6z. (Tarkistettu 29.9.2019)

Niinistö, Jussi (2016), Suojelupoliisin lausunnosta. - Jussiniinisto.fi, 3.11. https://jussiniinisto.fi/index. php/2016/11/suojelupoliisin-lausunnosta/. (Tarkistettu 29.9.2019)

Niinistö, Jussi (2017), Kaksoiskansalaisuus ja Puolustusvoimat. - Jussiniinisto.fi, 8.2. https://jussiniinisto.fi/index.php/2017/02/kaksoiskansalaisuus-ja-puolustusvoimat/. (Tarkistettu 29.9.2019)

Niinistö, Jussi (2018a), Politiikan toimittajien vieraana. - Jussiniinisto.fi, 8.3. https://jussiniinisto.fi/ index.php/2018/03/politiikan-toimittajien-vieraana/. (Tarkistettu 29.9.2019)

Niinistö, Jussi (2018b), 226. Maanpuolustuskurssin avajaisissa. - Jussiniinisto.fi, 10.9. https://jussiniinisto.fi/index.php/2018/09/226-maanpuolustuskurssin-avajaisissa/. (Tarkistettu 29.9.2019)

Niinistö, Jussi (2018c), Kaksoiskansalaisia koskeva lakiesitys syksyllä eduskuntaan. - Jussiniinisto. fi 2.10. https://jussiniinisto.fi/index.php/2018/10/kaksoiskansalaisia-koskeva-lakiesitys-syksyllaeduskuntaan/. (Tarkistettu 29.9.2019)

Oivo, Teemu, Pöllänen, Pirjo, Davydova-Minguet, Olga (2019, forthcoming), Puun ja kuoren välissä. - Muuttoliike ja arjen turvallisuus. Toim. Laura Assmuth, Ville-Samuli Haverinen, Pirjo Pöllänen. Tampere: Vastapaino.

Oivo, Teemu (2013), Foreign Agents in Russia: Discoursive Analysis on Foreign Agents in Russia 2012-2013. Kansainvälisten suhteiden pro gradu -tutkielma, Lapin yliopisto, Yhteiskuntatieteiden tiedekunta. http://hdl.handle.net/10138/42183. (Tarkistettu 29.9.2019)

Oivo, Teemu (2018), Keskustelu ja kehystäminen kaksoiskansalaisuuskysymyksessä. - Politiikasta. fi 28.6. https://politiikasta.fi/keskustelu-ja-kehystaminen-kaksoiskansalaisuuskysymyksessa/. (Tarkistettu 29.9.2019)

Pertsev, Andrei (2014), Gosduma uvidela v dvojnom graždanstve pjatuju kolonnu. - Kommersant 14.5. https://www.kommersant.ru/doc/2470245. (Tarkistettu 29.9.2019)

Perussuomalaiset (2015), Perussuomalaisten maahanmuuttopoliittinen ohjelma 2015. https://www. perussuomalaiset.fi/wp-content/uploads/2013/04/Maahanmuuttopoliittinen.pdf. (Tarkistettu 29.9.2019)

Ronkainen, Jussi (2009), Väliviivakansalaiset: Monikansalaisuus asemana ja käytäntönä. Joensuu: Joensuun Yliopisto.

Sazonov, Vsevolod (2014), Zakonoprojekt o zaprete dvojnogo graždanstva dlja vysokopostavlen- 
nyh gosslužaštših. 9.4. https://echo.msk.ru/blog/advokat_sazonov/1296842-echo/. (Tarkistettu 29.9.2019)

Škel, Tamara (2012), Tšinovnikam zapretili imet aktivy za granitsej. - Rossijskaja gazeta, 21.12. https://rg.ru/2012/12/21/chinovniki-site.html. (Tarkistettu 29.9.2019)

Skulte-Ouaiss, Jennifer (2015), 'Less is More, or More is Less'?: Securitized Citizenship in the Baltic States. - Extraterritorial Citizenship in Postcommunist Europe. Eds. Timofey Agarin, Ireneusz Karolewski. London: Rowman \& Littlefield International, 89-108.

SVT, Suomen virallinen tilasto (2018), Suomen kansalaisuuden saamiset. 2017. Helsinki: Tilastokeskus. http://www.stat.fi/til/kans/2017/kans_2017_2018-06-14_tie_001_fi.html. (Tarkistettu 29.9.2019)

SVT, Suomen virallinen tilasto (2019), Väestörakenne. Helsinki: Tilastokeskus. http://www.stat.fi/til/ vaerak/index.html. (Tarkistettu 29.9.2019)

Traunmüller, Karin, Agarin, Timofey (2015), Regulating Access to Citizenship after Territorial Changes: Extraterritorial Citizenship and the Russian Federation. - Extraterritorial Citizenship in Postcommunist Europe. Eds. Timofey Agarin, Ireneusz Karolewski. London: Rowman \& Littlefield International, 46-64.

Triadafilopoulos, Triadafilos (2007), Dual Citizenship and Security Norms in Historical Perspective. - Dual Citizenship in Global Perspective: From Unitary to Multiple Citizenship. Eds. Thomas Faist, Peter Kivisto. New York: Palgrave Macmillan, 27-41.

Varjonen, Sirkku, Linda, Arnold, Inga, Jasinskaja-Lahti (2013), 'We're Finns Here, and Russians There': A Longitudinal Study on Ethnic Identity Construction in the Context of Ethnic Migration. - Discourse \& Society, 24:1, 110-134.

Waterbury, Myra (2010), Bridging the divide: Towards a Comparative Framework for Understanding Kin State and Migrant-sending State Diaspora Politics. - Diaspora and Transnationalism: Concepts, Theories and Methods. Eds. Rainer Bauböck, Thomas Faist. Amsterdam University Press, 131-148.

Vink, Maarten, Schakel, Arjan, Reichely, David, Chun, Luk Ngo, de Groot, Gerard-Rene (2019), The International Diffusion of Expatriate Dual Citizenship. - Migration Studies, May 2019, 1-22. Zhurzhenko, Tatiana (2017), The Soviet War Memorial in Vienna. Geopolitics of Memory and the New Russian Diaspora in Post-Cold War Europe - Remembering the Second World War. Ed. Patrick Finney. Milton Park: Taylor and Francis, 89-114. 